\title{
PERAN FRUSTRASI PADA POLA ASUH OTORITER DAN AGRESI: MODEL MODERASI
}

\author{
Fahrul Rozi ${ }^{1}$ \& Subhan El Hafiz \\ Universitas Muhammadiyah Prof. Dr HAMKA, Jl.Limau 2, Kby. Baru, Jakarta 12130, Indonesia
}

Korespondensi:

${ }^{1}$ e-mail:fahrul.rozi.ishaq@gmail.com

\begin{abstract}
This study aims to determine the role of authoritarian parenting in increasing the aggression tendency among adolescents that is moderated by frustration. Participants in this study were 150 respondents. The instrument used were Parental Authory Questionnaire Scale (PAQ) created by Buri (1991), scale of frustration and Aggression Questionnaire Buss-Perry Scale (Buss \& Perry, 1992). Statistical analysis used model moderator analysis 1 according to PROCESS model (Hayes, 2013). The results of this study indicated that frustration significantly affects the role of authoritarian parenting style to the emergence of tendencies of aggression. Adolescents who experienced high (affect $=.0043 ; p<.001)$ and moderate (affect $=$ .6274; $p$ <.001) frustration significantly increases the influence of parental authoritarian parenting on the tendency of aggression. Meanwhile, adolescents' low frustration levels do not significantly trigger aggression even if they are exposed to authoritarian parenting style. This suggests that the level of frustration controls the tendency of aggressive behavior in adolescents who experience authoritarian parenting styles from their parents.
\end{abstract}

Article history:

Received 5 February 2018

Received in revised form 6 February 2018

Accepted 26 April 2018

Available online 31 October 2018

Keywords:

adolescents;

aggression;

authoritarian;

frustration;

parenting style

\begin{abstract}
Abstrak - Penelitian ini bertujuan untuk mengetahui peran pola asuh otoriter dalam meningkatkan kecenderungan perilaku agresi yang dimoderatori oleh frustrasi pada remaja. Responden penelitian ini berjumlah 150 responden. Instrumen yang digunakan adalah Parental Authory Questionnaire Scale (PAQ) yang disusun oleh Buri (1991), Skala frustrasi dan Aggression Questionnaire Buss-Perry Scale (Buss \& Perry, 1992). Teknik analisis statistik yang digunakan dalam penelitian ini adalah analisis efek moderator model 1 PROCESS (Hayes, 2013). Hasil penelitian ini menunjukkan bahwa frustrasi secara signifikan memengaruhi besar kecilnya peranan pola asuh otoriter terhadap munculnya kecenderungan perilaku agresi. Remaja yang mengalami frustrasi yang tinggi (affect $=1.0043$; $p<.001$ ) dan sedang (affect $=$ 0.6274; $p<.001)$ secara signifikan dapat meningkatkan peran pola asuh otoriter orang tua terhadap munculnya kecenderungan perilaku agresif. Namun, remaja yang mengalami frustrasi yang rendah tidak signifikan mendorong muncul perilaku agresi walaupau mereka mengalami gaya pengasuhan yang otoriter dari orang tua. Hal ini menunjukkan bahwa tingkat frustrasi pada remaja memegang peranan penting dalam terbentuknya kecenderungan perilaku agresi pada remaja yang mengalami gaya pengasuhan yang otoriter dari orang tua mereka.
\end{abstract}

Kata Kunci: remaja; agresi; otoriter; frustrasi; orang tua 


\section{PENDAHULUAN}

Pada masa transisi, remaja mengalami perubahan signifikan dalam berbagai aspek kehidupan. Perubahan bermula dari pengembangan fungsi anak dan dilanjutkan dengan periode konsolidasi, membangun identitas dan peran komitmen baru (Berk, 2010; Santrock, 1995; 2002; 2003; 2007). Perubahan hormonal dan pola asuh orang tua sering memberikan tekanan kepada remaja untuk menyesuaikan diri pada standar orang tua. Pola asuh negatif yang diterapkan orang tua, seperti pemberian batasan dan tekanan yang berlebihan yang dapat meningkatan konfrontasi anak terhadap orang tua dan menimbulkan berbagai jenis perilaku sosial yang negatif, seperti depresi, kenakalan remaja, dan agresivitas (Brown, Arnold, Dobbs, \& Doctoroff, 2007; Paikoff \& Brooks-Gunn, 1990; Putallaz \& Heflin, 1990).

Perilaku-perilaku sosial remaja yang kurang tepat tidak dapat terlepas dari peran pola asuh orang tua. Baumrind (1966), membagi pola pengasuhan orang tua menjadi tiga bagian yaitu otoritatif, otoriter dan permisif. Orang tua otoritatif (demokratis) adalah orang tua yang menuntut keberhasilan anaknya dengan baik dan responsif atas kondisi yang dialami oleh anak. Orang tua yang otoritatif lebih berhasil melindungi remaja dari penyalahgunaan narkoba dan menghasilkan remaja yang berkompeten (Baumrind, 1991). Sedangkan, orang tua yang otoriter lebih cenderung menghasilkan anak yang memiliki harga diri yang rendah (Rudy \& Grusec, 2006) dan perilaku sosial yang kurang tepat.

Pola asuh otoriter adalah pola pengasuhan orang tua yang memiliki kecenderungan mengedepankan kekuasaan yang sepihak dalam berinterakasi dengan remaja. Segala sesuatu yang dilakukan remaja dianggap salah dan bertentangan dengan maksud dan tujuan orang tua. Pengekangan, pembatasan dan penekanan yang diterapkan orang tua dalam pola pengasuhan membuat remaja merasa frustrasi (Papalia, Olds, \& Feldman, 2009; Santrock, 2003) sehingga sulit untuk mengungkapkan pendapat dan tidak dilibatkan dalam pembuatan peraturan. Kondisi ini mendorong mereka merasa kesepian, tertekan, cemas, marah, dan cenderung mengekspresikan kondisi tersebut dengan tindakan agresi dan perilaku antisosial lainnya (Wade \& Travis, 2007).

Gaya pengasuhan yang dominan memengaruhi kemarahan dan agresi adalah gaya pengasuhan orang tua yang otoriter (Zhou, Eisenberg, Wang, \& Reiser, 2004). Penjelasan yang mungkin tepat untuk asosiasi ini adalah orang tua dengan gaya pengasuhan otoriter tidak berperilaku secara baik dan tepat kepada remaja, sehingga remaja merasa tidak nyaman dan 
menunjukannya sebagai refleksi dari perilaku orang tua. Akibatnya, ketidaknyamanan dan perasaan tertekan tersebut membuat remaja tidak mampu mengatur agresitivitasnya ketika menghadapi sengketa atau konflik.

Orang tua dengan pola asuh otoriter dapat meningkatkan perilaku agresif pada remaja telah didukung oleh sejumlah studi (Coie \& Dodge, 1998; Ladd \& Pettit, 2002). Remaja menganggap orang tua yang tidak memadai, seperti orang tua dengan pola asuh otoriter dan permisif dapat mendorong meningkatnya frustrasi pada anak. Rasa frustrasi dapat memicu perilaku agresif yang didahului oleh amarah, seperti berteriak dan bersumpah, mendorong perusakan properti, dan bahkan penyerangan pribadi (Colorso, 2007). Individu yang mengalami frustrasi dapat meningkatkan perilaku agresifnya (Giumetti \& Markey, 2007).

Beberapa studi empiris mengenai perilaku agresif bermula dari perasaan frustrasi. Begitu juga dengan perilaku agresif yang ditunjukkan oleh remaja yang tidak terlepas dari rasa frustrasi yang dialami oleh mereka. Hambatan-hambatan dalam meregulasi emosi yang berasal dari pola asuh yang kurang tepat, sehingga memicu munculnya perasaan frustrasi. Pelampisan atas frustrasi, baik berupa perasaan jengkel maupun perasaan-perasaan negatif lainya, dapat berupa perilaku kekerasan dan agresif. Apabila remaja mengalami frustrasi, maka remaja cenderung ingin memuaskan atau melampiaskan perasaan frustrasi tersebut dengan perilaku agresif (Gerungan, 2004). Rozi dan Muhyiddin (2013) juga menunjukkan bahwa salah satu faktor munculnya perilaku agresif adalah frustrasi. Ketika individu merasa frustrasi terhadap sesuatu, seseorang, atau peristiwa tertentu, maka mendorong munculnya perilaku agresif (Dollard dkk., dalam Mercer \& Clayton, 2012) dan perilaku agresif juga merupakan pelampiasan dari perasaan frustrasi (Sarwono, 1999). Ketidakmampuan remaja dalam mengelola agresivitasnya disebabkan oleh pola otoriter orang tua (Shahida, 2013).

Peran gender dalam penerimaan reaksi frustrasi tentu berbeda antara pria dan wanita. Pria memiliki kekuatan asosiasi yang lebih tinggi dibandingkan dengan reaksi frustrasi wanita dalam situasi tertentu (Ko dkk., 2008). Perasaan frustrasi yang dimiliki oleh pria dapat mendorong meningkatnya agresivitas dalam merespons sesuatu pada konteks tertentu. Munculnya agresivitas pada pria juga dipicu oleh berbagai faktor, salah satunya adalah testosteron (Archer, 1991), status, persaingan, dan motif perkawinan, yang juga menunjukkan bahwa pria cenderung menunjukkan perilaku agresif secara langsung dibandingkan wanita (Griskevicius dkk., 2009).

Remaja pria yang terlibat kasus kekerasan terkadang mengarah kepada tindakan kriminalitas yang berujung kepada hukuman pidana atas tindak kekerasan yang telah dilakukan. Hukuman kurungan menjadi konsekuensi yang tak terlepaskan dari hukuman pidana dan menjadi warga 
binaan di lembaga pemasyrakatan. Data Pemasyarakatan Direktorat Jendral Pemasyarakatan Kementrian Hukum dan HAM pada Kantor Wilayah DKI Jakarta menunjukkan adanya peningkatan jumlah penghuni di Lembaga Pemasyarakatan Anak dan Remaja. Fakta lain juga ditemukan yang mengarah kepada tren peningkatan kriminalitas yang dilakukan oleh anak maupun remaja di beberapa wilayah di Indonesia (Kementerian Hukum dan HAM, 2015).

Peningkatan jumlah anak didik pemsarakatan (adikpas) dan tindakan kriminalitas yang mengandung kekerasan juga mendorong kecenderungan perilaku agresif yang tinggi pada adikpas. Tingginya perilaku agresif juga didukung oleh Poetra (2013) bahwa seluruh adikpas yang diteliti memiliki agresivitas yang tinggi pada dimensi fisik dan verbal. Tingginya agresivitas adikpas di lingkungan lembaga pemasyarakatan anak menunjukkan bahwa pemilihan adikpas sebagai responden penelitian cukup baik untuk melihat faktor-faktor perilaku yang memicu munculnya agresivitas pada remaja.

Peningkatan konflik antara orang tua dengan remaja, efek negatif yang timbul dari gaya pengasuhan orang tua otoriter, dan adanya peningkatan frustrasi yang dialami oleh remaja diduga memiliki pengaruh terhadap munculnya perilaku agresif. Daya tarik utama dari penelitian ini berupaya untuk melihat efek dari gaya pengasuhan orang tua yang otoriter terhadap peningkatan agresivitas remaja dengan mempertimbangkan tinggi dan rendahnya tingkat frustrasi yang dialami oleh remaja.

Adapun model yang akan diuji dalam penelitian ini, tergambar dalam bagan berikut:

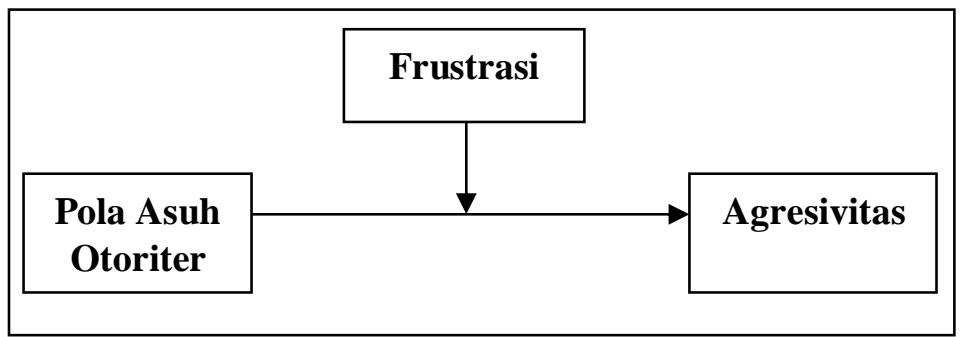

Bagan 1. Model Penelitian

\section{METODE}

\section{Partisipan}

Partisipan yang sesuai dengan kriteria inklusif pada penelitain ini berjumlah 150 remaja dengan rentang usia $14-18$ tahun $(M=16.68, S D=1.035)$. Teknik sampling yang digunakan adalah 
non-probability sampling. Partisipan tersebar dalam Lembaga Permasyarakatan Anak dan Remaja di Jakarta.

\section{Desain}

Desain penelitian yang digunakan adalah analisis efek moderasi. Dalam penelitian ini, data dan informasi dikumpulkan dengan kuesioner dan hasilnya akan dianalisis dengan efek moderasi model 1 PROCESS (Hayes, 2013), dan dilakukan pengujian hipotesis yang telah diajukan di awal penelitian (Riduwan, 2006). Setelah mengetahui signifikansi efek moderasi frustrasi dalam pengaruh pola asuh otoriter terhadap agresivitas, maka akan dilakukan pengujian signifikansi di setiap tingkat frustrasi, baik tinggi, sedang maupun rendah, dalam pengaruh pola asuh orang tua yang otoriter terhadap agresivitas.

\section{Instrumen}

Instrumen pertama yang digunakan dalam penelitian ini adalah skala pola asuh otoriter yang diadaptasi dari Parental Authory Questionnaire Scale (Buri, 1991). PAQ terbagi dari tiga sub bagian yaitu pola asuh otoriter, pola asuh demokratis, dan pola asuh permisif. Sub skala pola asuh yang digunakan dalam penelitian ini adalah sub pola asuh otoriter orang tua dengan jumlah sebanyak 20 butir, dengan Cronbach Alpha sebesar .877. Sub pola asuh otoriter orang tua terbagi menjadi dua yaitu sub pola asuh orang tua otoriter ibu dan ayah, dengan masing-masing bagian memiliki 10 butir. Sub pola asuh otoriter ibu memiliki nilai Cronbach Alpha sebesar .803 dan .778 untuk sub pola asuh otoriter ayah.

Instrumen kedua yang digunakan dalam penelitian ini adalah Skala Frustrasi yang disusun oleh tim peneliti, dengan jumlah item sebanyak 23 butir dengan Cronbach Alpha sebesar .877. Skala Frustrasi terbagi dalam dua bagian yaitu respon frustrasi ke dalam dan respon frustrasi ke keluar. Penyusunan skala frustrasi lebih menekankan kepada frustrasi yang dialami oleh remaja berdasarkan aspek-aspek yang sesuai dengan teori frustrasi yang dikemukakan oleh Supraptik dan Sumarmo (2003) dan pengembangan konten butir berdasarkan pada kondisi frustrasi Adikpas di lembaga pemasyarakatan. Setelah diterapkan validitas isi pada setiap butirnya, dilanjutkan dengan tryout, dan analisis validitas konstruknya. Total butir sebelum tryout sebanyak 39 butir. Setelah dilakukan validiasi, keseluruhan butir berjumlah 23 butir dan keseluruhan butir tersebut digunakan dalam penelitian ini. 
Instrumen ketiga yang digunakan dalam penelitian ini adalah skala perilaku agresif dengan menggunakan skala yang diadaptasi dari Aggression Questionnaire Buss-Perry Scale (Buss \& Perry, 1992). Skala Agresif ini terdiri dari 29 butir dengan Cronbach’s Alpha sebesar .890.

\section{Analisis Data}

Analisis statistik yang digunakan dalam menentukan peran moderator frustrasi dalam pengaruh pola asuh otoriter terhadap perilaku agresi pada remaja adalah efek moderasi model 1 yang dikembangkan oleh Hayes (2013). Variabel independen atau prediktor (IV) disimbolkan dengan huruf X yaitu pola asuh orang tua otoriter. Variabel dependen atau hasil (DV) disimbolkan dengan huruf Y yaitu agresivitas. Variabel moderator disimbolkan dengan huruf M yaitu frustrasi. Moderator adalah variabel yang menentukan kondisi dan hasil pangaruh dari prediktor $(\mathrm{X})$ terhadap hasil (Y). Moderator dapat menjelaskan ketika X dan Y terkait atau memiliki koefisien korelasi yang signifikan. Moderasi mengandung efek interaksi, karena variabel moderasi dapat mengubah arah, memperkecil atau memperbesar hubungan antara dua variabel. Sebuah efek moderasi dapat menjadipeningkat, dimana peningkatan moderator akan meningkatkan efek dari prediktor (X) terhadap hasil (Y). Efek moderasi juga dapat menjadi penurun, dimana peningkatan moderator akan mengurangi efek dari prediktor pada hasil, atau menjadi antagonis, dimana peningkatan moderator akan membalikkan efek dari prediktor pada hasil.

\section{ANALISIS DAN HASIL}

Penelitian ini membuktikan bahwa adanya peran moderator frustrasi dalam pengaruh pola asuh otoriter orang tua terhadap kecenderungan perilaku agresif pada remaja. Gambaran peran moderator frustrasi tercakup sebagai berikut :

Tabel 1.

Efek Moderasi Frustrasi pada Pengaruh PAO kepada Agresivitas

\begin{tabular}{lccc}
\hline & Coeff. & SE & $\boldsymbol{t}$ \\
\hline Intercept & $93.3918^{*}$ & 1.0296 & $90.7071^{*}$ \\
Frustrasi (M) & $.3463^{*}$ & .0824 & $4.2039^{*}$ \\
Pola Asuh Otoriter (X) & $.6274^{*}$ & .0954 & $6.5777^{*}$ \\
PAOx Frus (XM) & $.0286^{*}$ & .0078 & $3.6558^{*}$ \\
\hline
\end{tabular}

Keterangan: $* P<.001$

$$
R^{2}=.4621, \boldsymbol{M S E}=152.6601 ; \boldsymbol{F}(3,150)=39.1289, \boldsymbol{p}<.001
$$


Data di atas menujukkan bahwa moderator frustrasi memiliki efek interaksi dalam hubungan antara pola asuh otoriter dengan agresivitas. Hubungan antara pola asuh otoriter dengan agresivitas bervariatif berdasarkan pada tingkatan frustrasi yang dirasakan oleh remaja. Dengan kata lain, hubungan antara pola asuh otoriter $(\mathrm{X})$ terhadap agresivitas $(\mathrm{Y})$ tergantung pada variabel frustrasi (M). Analisis statistik menunjukkan adanya peran moderator frustrasi yang signifikan (M) dalam hubungan pola asuh otoriter (X) terhadap agresivitas (Y) dengan koefisien interaksi sebesar .0286 dan nilai $t$ sebesar $3.6558(P<.01)$.

Efek Pola Asuh Otoriter (PAO) dalam meningkatkan kecenderungan perilaku agresif lebih besar pada remaja yang mengalami frustrasi tingkat sedang dan tinggi dibandingkan remaja yang mengalami frustrasi tingkat rendah. Data tercakup sebagai berikut :

Tabel 2.

Pengaruh PAO terhadap Agresivitas Remaja Bergantung pada Tingkatan Frustrasi

\begin{tabular}{lccc}
\hline \multirow{2}{*}{ PAO } & \multicolumn{3}{c}{ Frustrasi } \\
\cline { 2 - 4 } & Low & Agerage & High \\
\hline Low PAO & 85.97 & 85.9 & 85.85 \\
Average PAO & 97.95 & 93.39 & 88.83 \\
High PAO & 109.93 & 100.87 & 91.81 \\
\hline
\end{tabular}

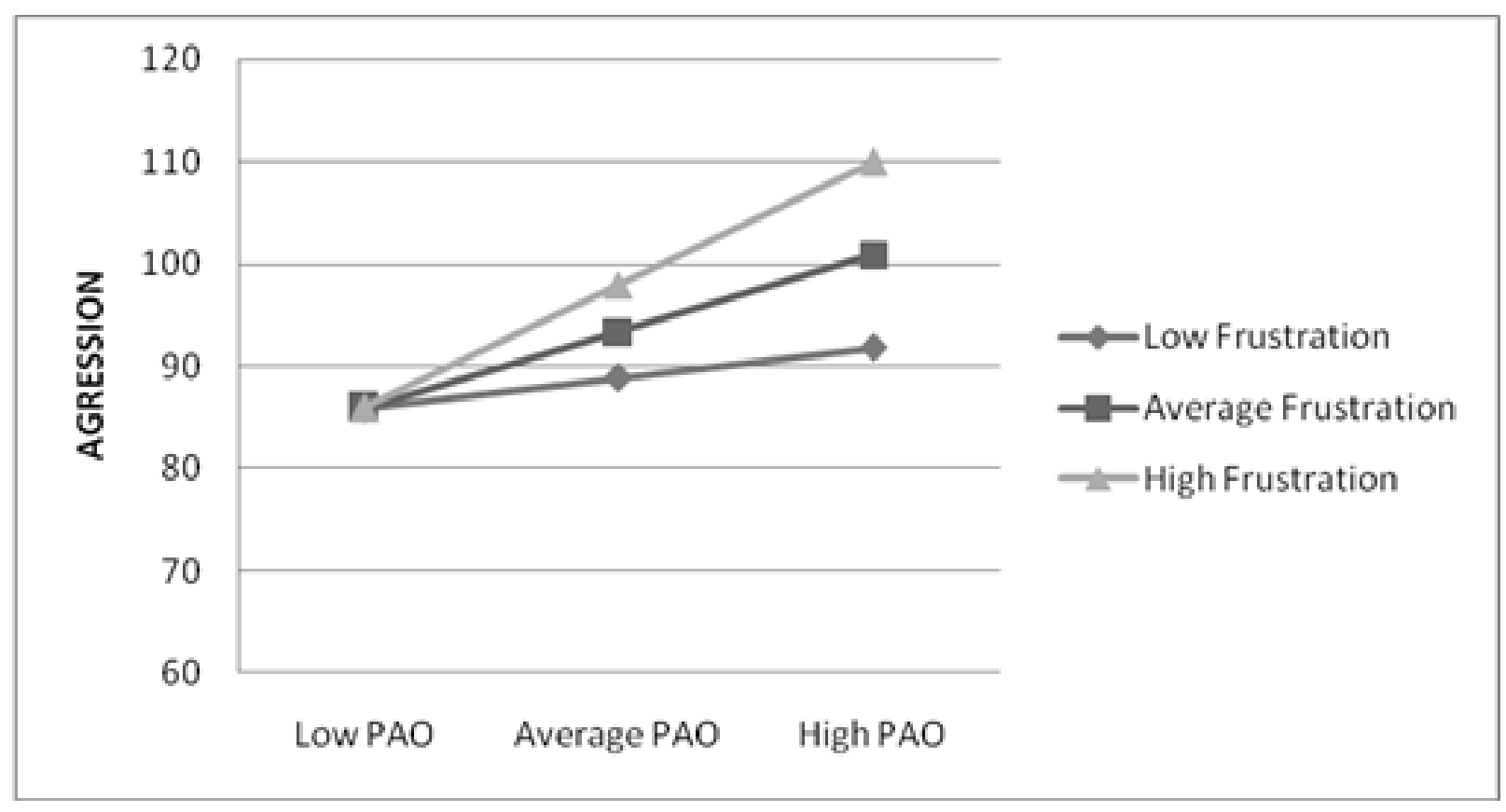

Bagan 2. Efek Tingkat Frustrasi dalam Pengaruh PAO terhadap Agresivitas 
Tabel 3.

Pengaruh PAO terhadap Agresivitas Remaja Bergantung pada Tingkatan Frustrasi

\begin{tabular}{clcccc}
\hline Prediktor & Moderasi & \multicolumn{4}{c}{ Agresi } \\
\cline { 3 - 6 } & & Affect & Std. Error & $t$ & $p$ \\
\hline Pola Asuh & $\mathrm{F}_{\text {High }}$ & 1.0043 & 8.7455 & 8.7455 & .0000 \\
Otoriter & $\mathrm{F}_{\text {Mean }}$ & .6274 & .0954 & 6.5777 & .0000 \\
& $\mathrm{~F}_{\text {Low }}$ & .2505 & .1621 & 1.5453 & .1244 \\
\hline
\end{tabular}

Berdasarkan gambar dan data di atas, hasil menunjukkan bahwa frustrasi tingkat rendah memberikan efek positif tidak signifikan sebesar .2505, nilai $t$ sebesar $1.5453(P>.01)$ terhadap kekuatan hubungan antara pola asuh otoriter orang tua (X) dengan agresivitas (Y). Frustrasi tingkat sedang memberikan efek positif signifikan sebesar .6274 , nilai $t$ sebesar $6.5777(P<.01)$ terhadap kekuatan hubungan antara pola asuh otoriter orang tua $(\mathrm{X})$ dengan agresivitas $(\mathrm{Y})$. Sedangkan, frustrasi tingkat tinggi memberikan efek positif signifikan sebesar 1.0043, nilai $t$ sebesar $8.7455(P$ $<.01)$ terhadap kekuatan hubungan antara pola asuh otoriter orang tua $(\mathrm{X})$ dengan agresivitas $(\mathrm{Y})$.

Analisis moderasi statistik menunjukkan bahwa frustrasi dapat menyebabkan kekuatan peranan atau hubungan antara pola asuh otoriter orang tua $(\mathrm{X})$ dan agresivitas $(\mathrm{Y})$ menjadi berbeda. Orang tua yang mengasuh anaknya dengan pola pengasuhan otoriter (X) akan berbeda dalam menghasilkan tingkat kecenderungan agresi (Y) ketika adanya perbedaan tingkat frustrasi yang dialami remaja $(\mathrm{M})$. Peranan pola asuh otoriter orang tua terhadap munculnya kecenderungan perilaku agresif lebih besar ketika remaja mengalami frustrasi tingkat tinggi dan sedang dibandingkan dengan remaja yang mengalami frustrasi yang rendah. Meskipun tingkat frustrasi sama-sama menguatkan peranan pola asuh otoriter orang tua $(\mathrm{X})$ terhadap agresivitas $(\mathrm{Y})$ remaja, namun frustrasi tingkat tinggi dan sedang lebih menyebabkan $\mathrm{X}$ memengaruhi $\mathrm{Y}$ yang lebih besar dibanding frustrasi tingkat rendah.

Oleh karenanya, di antara individu yang mengalami frustrasi yang tinggi $\left(F_{H i g h}\right)$ dan sedang $\left(F_{\text {Mean }}\right)$ memiliki kecenderungan semakin kuatnya pengaruh pola asuh otoriter orang tua terhadap munculnya perilaku agresi. Namun, di antara individu yang mengalami frustrasi yang rendah $\left(F_{\text {Low }}\right)$ tidak terdapat kecenderungan yang signifikan terhadap pengaruh pola asuh otoriter orang tua terhadap munculnya perilaku agresi. Hal ini menunjukan bahwa moderator frustrasi memiliki fungsi sebagai peningkat, dimana peningkatan frustrasi akan meningkatkan efek pola asuh otoriter orang tua terhadap agresivitas remaja. Dengan kata lain, pengaruh pola asuh otoriter orang tua menyebabkan muncul kecenderungan perilaku agresif tergantung pada tinggi rendahya tingkat frustrasi yang dialami oleh remaja. Jika remaja mengalami frustrasi yang tinggi dan sedang, maka pengaruh pola asuh otoriter orang tua akan semakin kuat memunculkan kecenderungan perilaku 
agresi. Akan tetapi, jika remaja mengalami frustrasi yang rendah, maka pengaruh pola asuh otoriter orang tua tidak memunculkan kecenderungan perilaku agresi.

Penelitian ini juga menunjukkan bahwa pola asuh otoriter orang tua, baik ibu maupun ayah, dapat meningkatkan kecenderungan perilaku agresif yang lebih besar pada remaja yang mengalami frustrasi tingkat sedang dan tinggi dibanding remaja yang mengalami frustrasi tingkat rendah. Gambaran interaksi moderasi frustrasi pada pola asuh otoriter ibu dan ayah tercakup sebagai berikut.

Tabel 4.

Interaksi Moderasi Frustrasi pada PAO Ibu dan Ayah

\begin{tabular}{lccc}
\hline \multicolumn{1}{c}{ Interaksi } & Coeff. & $\boldsymbol{t}$ & $\boldsymbol{p}$ \\
\hline PAO x Frustration & .0286 & 3.6558 & .0004 \\
PAO $_{\text {MotherX Frustration }}$ & .0553 & 3.3255 & .0011 \\
PAO $_{\text {FatherX Frustration }}$ & .0521 & 3.1576 & .0019 \\
\hline
\end{tabular}

Tabel 5.

Pengaruh PAO Ibu dan Ayah terhadap Agresivitas Remaja Bergantung pada Tingkatan Frustrasi

\begin{tabular}{clcccc}
\hline Prediktor & Moderasi & \multicolumn{4}{c}{ Agresi } \\
\cline { 3 - 5 } & & Affect & $S E$ & $t$ & $p$ \\
\hline Pola Asuh & $\mathrm{F}_{\text {High }}$ & 1.8125 & .2696 & 6.7240 & .0000 \\
Otoriter Ibu & $\mathrm{F}_{\text {Mean }}$ & 1.0840 & .1542 & 7.0303 & .0000 \\
& $\mathrm{~F}_{\text {Low }}$ & .3555 & .2662 & 1.3353 & .1838 \\
\hline Pola Asuh & $\mathrm{F}_{\text {High }}$ & 1.7906 & .2669 & 6.7089 & .0000 \\
Otoriter Ayah & $\mathrm{F}_{\text {Mean }}$ & 1.1040 & .2191 & 5.0381 & .0000 \\
& $\mathrm{~F}_{\text {Low }}$ & .4174 & .3455 & 1.2082 & .2289 \\
\hline
\end{tabular}

Berdasarkan gambar dan data di atas menunjukkan bahwa frustrasi tingkat rendah memberikan efek positif tidak signifikan sebesar .4174 , nilai $t$ sebesar $1.2082(P>.01)$ terhadap kekuatan hubungan antara pola asuh otoriter ayah (X) dengan agresivitas (Y). Frustrasi tingkat sedang memberikan efek positif signifikan sebesar 1.1040, nilai $t$ sebesar $5.0381(P<.01)$ terhadap kekuatan hubungan antara pola asuh otoriter ayah (X) dengan agresivitas (Y). Sedangkan frustrasi tingkat tinggi memberikan efek positif signifikan sebesar 1.7906, nilai $t$ sebesar $6.7089(P<.01)$, terhadap kekuatan hubungan antara pola asuh otoriter ibu (X) dengan agresivitas (Y).

\section{DISKUSI}

Orang tua yang menerapkan pola asuh otoriter memiliki kecenderungan untuk melakukan tindak kekerasan terhadap anak atau remaja. Pola asuh kekerasan yang ditunjukkan orang tua akan 
mendorong anak untuk meniru (Bandura, Ross, \& Ross, 1963) dengan melakukan hal yang serupa dalam interakasinya dengan masyarakat. Pola kekerasan yang ditunjukkan oleh orang tua otoriter dan efek meniru perilaku kekerasan akan mendorong remaja untuk melakukan tindakan kekerasan. Hal ini merujuk pada penelitian yang telah dilakukan oleh Chen, Dong, dan Zhou (1997) yang menunjukkan bahwa pola asuh otoriter memiliki korelasi positif yang signifikan dengan agresivitas.

Meta analisis yang telah dilakukan oleh Kawabata, Alink, Tseng, Van Ijzendoorn, dan Crick (2011) menunjukkan bahwa remaja yang mengalami kekerasan dalam pengasuhan akan cenderung melakukan tindakan agresif. Studi empiris lainnya juga menunjukkan bahwa orang tua yang mendominasi, tidak hangat dan mengabaikan dapat memengaruhi perilaku agresif pada remaja (Gao, Zhang, \& Fung, 2015). Tipe pengasuhan ini membuat remaja tidak merasa nyaman dan tertekan. Akibatnya, remaja tidak memiliki kemampuan untuk meregulasi emosinya dengan baik. Minimnya kemampuan ini dapat memberikan dampak negatif, seperti ketidakmampuan dalam mengatur impuls agresif ketika sedang menghadapi sengketa atau konflik. Munculnya perilaku agresif dapat dipicu oleh tindakan kekerasan yang mereka dapatkan dari pola asuh orang tua yang otoriter.

Banyaknya penelitian yang mengungkapkan tentang penerapan pola asuh otoriter dapat mendorong munculnya perilaku agresif pada remaja (Casas dkk., 2006). Hal ini menunjukkan bahwa orang tua memiliki peran yang penting dalam pembentukkan perilaku remaja. Interaksi yang buruk antara orang tua dengan remaja tentu memberikan dampak emosional yang negatif, sehingga remaja merasa tertekan, cemas dan marah. Pada akhirnya, remaja akan mengalami ketidakmampuan dalam meregulasi emosi yang baik.

Pola asuh orang tua yang otoriter dapat memengaruhi kemampuan anak dalam meregulasi emosi (Eisenberg dkk., 1999). Ketidakmampuan remaja dalam meregulasi emosi tentu memberikan peluang munculnya permasalahan sosial, salah satunya adalah perilaku agresif. Pola pengasuhan kekerasan yang dilakukan oleh orang tua memperlihatkan adanya interaksi fisik dan emosional yang agresif. Hal ini akan menjadi salah satu acuan bagaimana remaja berinteraksi dengan orang lain, sehingga remaja akan menjadi sosok tidak berkompeten dalam interkasi dengan teman sebaya (Parke, Cassidy, Burks, Carson, \& Boyum, 1992).

Gaya pengasuhan otoriter identik dengan gaya pengasuhan dengan kekerasan (harsh parenting) dapat berpengaruh terhadap emosi negatif remaja, baik remaja laki-laki maupun perempuan. Hal ini sesuai dengan penelitian Chang, Schwartz, Dodge, dan McChan (2013) menunjukkan bahwa pola asuh ibu yang keras lebih kuat dalam memengaruhi regulasi emosi anak dibandingkan pola asuh ayah. Sedangkan, pola asuh ayah yang keras memiliki efek yang lebih kuat 
pada tingkat agresivitas anak laki-laki dibandingkan dengan anak perempuan. Pola asuh ayah yang mengedepankan kekerasan lebih memengaruhi anak laki-laki dibandingkan anak perempuan dalam peningkatan tingkat agresivitas. Pengasuhan orang tua dengan kekerasan akan berdampak pada regulasi emosi anak sehingga dapat meningkatkan perilaku agresif.

Emosi negatif yang berasal dari ketidakmampuan individu dalam meregulasi emosinya tentu mendorong individu mengalami frustrasi (Eisenberg \& Fabes, 1994). Pola asuh otoriter tidak hanya dapat memengaruhi kemampuan regulasi emosi individu, tetapi juga dapat memengaruhi munculnya rasa frustrasi. Hal ini diperkuat oleh hasil penelitian Zhou dkk. (2004) bahwa pola asuh otoriter berhubungan dengan disposisi marah atau frustrasi yang tinggi.

Studi empiris telah membuktikan bahwa orang tua yang memperlakukan remaja dengan pola asuh otoriter atau kekerasan dapat memunculkan rasa frustrasi, sehingga mendorong remaja untuk berperilaku agresif. Kemudian, bagaimana jika remaja yang terpapar dengan pola asuh otoriter tidak mengalami frustrasi. Penelitian ini mencoba menjawab pernyataan tersebut. Remaja yang tidak mengalami frustrasi, tidak akan terdorong untuk berperilaku agresif walaupun remaja tersebut mendapatkan pola asuh otoriter dari orang tuanya. Perilaku agresif akan muncul ketika remaja mengalami frustrasi tingkat tinggi dan sedang dibandingkan dengan remaja yang mengalami frustrasi tingkat rendah. Meskipun tingkat frustrasi sama-sama menguatkan peranan pola asuh otoriter orang tua terhadap agresivitas remaja, tetapi frustrasi tingkat tinggi dan sedang cenderung menyebabkan perilaku agresif lebih besar dibandingkan remaja yang mengalami frustrasi tingkat rendah.

Terlihat jelas bahwa frustrasi yang dialami oleh remaja dapat mendorong mereka berperilaku agresif. McClelland dan Apicella (dalam Saxena, 2005) telah melakukan studi laboratorium yang menunjukkan hubungan sebab akibat antara frustrasi dan agresivitas. Ketergantungan frustrasi dalam hubungan kausalitas dengan agresivitas memperlihatkan bahwa munculnya agresivitas dalam berbagai model penelitian tergantung dari seberapa besar tingkat frustrasi, walaupun dibandingkan dengan variabel-variabel yang mendorong dalam munculnya perilaku agresif. Frustrasi menentukan kekuatan pengaruh pola asuh otoriter orang tua terhadap kecenderungan perilaku agresif, namun tergantung pada tingkat tinggi rendahnya frustrasi yang dialami oleh remaja.

Penelitian ini memperkuat teori frustrasi-agresi di mana agresi adalah reaksi alami dari frustrasi (Dollard dkk., 1939). Hipotesis frustrasi-agresi menyatakan bahwa agresivitas selalu merupakan konsekuensi dari frustrasi dengan dua proposisi yaitu perilaku agresif selalu muncul karena adanya frustrasi, dan setiap frustrasi mengarah pada perilaku agresif. Namun, penelitian 
selanjutnya menunjukkan bahwa agresivitas bukan merupakan reaksi tunggal yang diakibatkan oleh frustrasi, tetapi hal tersebut dapat dikaitkan dengan pengalaman belajar sebelumnya (Bandura 1973; Miller \& Dollard, 1941). Pengalaman belajar mengenai kekerasan dari pola pengasuhan orang tua yang otoriter tentu menjadi pendorong remaja mengalami frustrasi. Oleh karena itu, rasa frustrasi yang dirasakan oleh remaja dan pengalaman belajar kekerasan yang berasal dari orang tua otoriter memperkuat pengaruh frustrasi terhadap agresivitas pada remaja.

Terdapat dua keterbatasan penelitian ini. Pertama, peneliti tidak meneliti mengenai jenis kelamin pada partisipan penelitian. Faktanya, terdapat perbedaan efek antara remaja pria dan wanita ketika mengalami pola asuh yang mengandung kekerasan yang tentu menjadi pembahasan tersendiri pada masing-masing pengasuahan orang tua, baik ayah maupun ibu. Kedua, peneliti tidak mengikutsertakan variabel marah dalam analisis moderasi, dimana variabel marah menjadi salah satu faktor penentu munculnya agresivitas ketika remaja mengalami frustrasi.

\section{SIMPULAN DAN SARAN}

\section{Simpulan}

Penelitian ini bertujuan menguji efek moderasi frustrasi dalam pengaruh pola asuh otoriter terhadap perilaku agresif remaja, baik remaja yang mengalami frustrasi tinggi, sedang dan rendah. Berdasarkan analisis data menunjukkan bahwa frustrasi secara signifikan memiliki efek moderasi dalam pengaruh pola asuh otoriter terhadap agresivitas remaja. Efek moderasi frustrasi tergantung pada tingkat frustrasi, dimana remaja yang mengalami tingkat frustrasi tinggi dan sedang akan memberikan efek moderasi yang signifikan dalam kekuatan pengaruh pola asuh otoriter terhadap agresivitas remaja. Sedangkan, remaja yang mengalami tingkat frustrasi yang rendah, tidak secara signifikan memperkuat pengaruh pola asuh orang tua otoriter terhadap kecenderungan agresivitas pada remaja.

\section{Saran Teoretis}

Berikut adalah saran bagi penelitian lanjutan maupun langkah-langkah yang cukup bermakna untuk menurunkan kecenderungan perilaku agresif pada remaja. Pertama, diperlukan adanya program-program yang dapat menangani frustrasi pada remaja yang mengalami pengasuhan otoriter dari orang tua mereka, seperti olahraga, konseling remaja dan pelatihan mengatasi stres yang adekuat. Program tersebut bertujuan untuk menurunkan tingkat frustrasi pada remaja, 
sehingga dapat menurunkan kecenderungan perilaku agresif pada remaja. Kedua, penggunaan alat ukur frustrasi yang digunakan dalam penelitian ini lebih menekankan pada kondisi frustrasi yang umum dirasakan oleh individu dan tidak mengkhususkannya kepada konteks frustrasi pada remaja. Agar mendapatkan gambaran variabel yang lebih tepat, maka perlu disusun alat ukur frustrasi yang sesuai dengan konteks remaja. Oleh karenanya, penelitian selanjutnya perlu melakukan analisis Exploratory Factor Analysis untuk melihat pengelompokan faktor-faktor yang membentuk frustrasi pada remaja. Ketiga, penelitian selanjutnya perlu menentukan partisipan penelitian yang lebih heterogen dalam fase remaja, seperti komunitas remaja, tingkat pendidikan dan ekonomi yang berbeda, suku dan etnis yang berbeda, serta memperhatihan peran jenis kelamin di dalam penelitiannya. Data heterogen dapat mendorong analisis yang lebih komprehensif dan mendalam sehingga memicu penemuan-penemuan yang terbaru dan solusi yang lebih adekuat terhadap permasalahan remaja, khususnya mengenai frustrasi dan agresivitas remaja pada remaja yang mengalamai pola asuh yang otoriter.

\section{REFERENSI}

Archer, J. (1991). The influence of testosterone on human aggression. British journal of psychology, 82(1), 1-28.

Bandura, A. (1973). Aggression: A social learning analysis. Englewood Cliffs, NJ: Prentice-Hall.

Bandura, A., Ross, D., \& Ross, S. A. (1963). Imitation of film-mediated aggressive models. The Journal of Abnormal and Social Psychology, 66(1), 3.

Baumrind, D. (1966). Effects of authoritative parental control on child behavior. Child development, 37(4), 887-907.

Baumrind, D. (1991). The influence of parenting style on adolescent competence and substance use. The Journal of Early Adolescence, 11(1), 56-95.

Berk, L. (2010). Live Span Development. Yogyakarta: Pustaka Pelajar.

Brown, S. A., Arnold, D. H., Dobbs, J., \& Doctoroff, G. L. (2007). Parenting predictors of relational aggression among Puerto Rican and European American school-age children. Early Childhood Research Quarterly, 22(1), 147-159.

Buri, J. R. (1991). Parental authority questionnaire. Journal of Personality Assesment, 57(1), 110119. 
Buss, A. H., \& Perry, M. P. (1992). The aggression questionnaire. Journal of Personality and Social Psychology, 63(3), 452-459.

Casas, J. F., Weigel, S. M., Crick, N. R., Ostrov, J. M., Woods, K. E., Yeh, E. A. J., \& HuddlestonCasas, C. A. (2006). Early parenting and children's relational and physical aggression in the preschool and home contexts. Journal of Applied Developmental Psychology, 27(3), 209227.

Chang. L., Schwartz. D., Dodge, K. A., \& McChan. C. (2003). Harsh parenting in relation to child emotion regulation and Aggression. Journal of Family Psychology, 17(4), 598-606.

Chen, X., Dong, Q., \& Zhou, H. (1997). Authoritative and authoritarian parenting practices and social and school performance in Chinese children. International Journal of Behavioral Development, 21(4), 855-873.

Coie, J. D., \& Dodge, K. A. (1998). Aggression and antisocial behavior. In W. Damon \& N. Eisenberg (Eds.), Handbook of child psychology (hlm. 779-862). New York, NY: Wiley \& Sons.

Colorso, B. (2007). Stop Bulliying. Jakarta: Serambi Ilmu.

Dollard, J., Miller, N. E., Doob, L. W., Mowrer, O. H., \& Sears, R. R. (1939). Frustration and aggression. New Haven, CT: Yale University Press.

Eisenberg, N., \& Fabes, R. A. (1994). Mother's reactions to children's negative emotions: Relations to children's temperament and anger behavior. Merill-Palmer Quarterly, 1982, 138-156.

Eisenberg, N., Fabes, R. A., Shepard, S. A., Guthrie, I. K., Murphy, B. C., \& Reiser, M. (1999). Parental reactions to children's negative emotions: Longitudinal relations to quality of children's social functioning. Child development, 70(2), 513-534.

Gao, Y., Zhang, W., \& Fung, A. L. C. (2015). The associations between parenting styles and proactive and reactive aggression in Hong Kong children and adolescents. International Journal of Psychology, 50(6), 463-471.

Gerungan, W. A. (2004). Psikologi Sosial. Bandung: Refika Aditama.

Giumetti, G. W., Markey, P. M. (2007). Violent video games and anger as predictors of aggression. Journal of Research in Personality, 41(6), 1234-1243.

Griskevicius, V., Tybur, J. M., Gangestad, S. W., Perea, E. F., Shapiro, J. R., \& Kenrick, D. T. (2009). Aggress to impress: hostility as an evolved context-dependent strategy. Journal of Personality and Social Psychology, 96(5), 980-994.

Hayes, F. A. (2013). Introduction mediation, moderation adn conditional process analysis. New York, NY: Guilford Press. 
Kawabata, Y., Alink, L. R., Tseng, W. L., Van Ijzendoorn, M. H., \& Crick, N. R. (2011). Maternal and paternal parenting styles associated with relational aggression in children and adolescents: A conceptual analysis and meta-analytic review. Developmental Review, 31(4), 240-278.

Kementerian Hukum dan HAM. (2015). Sistem Database Pemasyarakatan. Ditemu kembali dari http://smslap.ditjenpas.go.id/

Ko, C. H., Yen, J. Y., Yen, C. F., Chen, C. S., \& Wang, S. Y. (2008). The association between Internet addiction and belief of frustration intolerance: the gender difference. Cyberpsychology \& Behavior, 11(3), 273-278.

Ladd, G. W., \& Pettit, G. S. (2002). Parenting and the development of children's peer relationships. In M. H. Borenstein (Ed.), Handbook of parenting (2nd ed., hlm. 377-409). Mahwah, NJ: Lawrence Erlbaum Associate.

Mercer, J., \& Clayton, D. (2012). Psikologi Sosial (N. F. Widuri, Penerj.). Jakarta: Erlangga.

Miller, N. E., \& Dollard, J. (1941). Social learning and imitation. New Haven, CT: Yale University Press.

Paikoff, R. L., \& Brooks-Gunn, J. (1990). Physiological processes: What role do they play during the transition to adolescence? In R. Montemayor, G. Adams, \& T. Gullotta (Eds.), Advances in adolescent development: The transition from childhood to adolescence (hlm. 63-81). Newbury Park, CA: Sage.

Papalia, D. E., Olds, S. W., \& Feldman, R. D.(2007). Human Development (10th ed.). New York, NY: McGraw-Hill.

Parke, R. D., Cassidy, J., Burks, V. M., Carson, J. L., \& Boyum, L. (1992). Familial contribution to peer competence among young children: The role of interactive and affective processes. Family-peer relationships: Modes of linkage, 107-134.

Poetra, C. W. (2013). Gambaran agresivitas Adikpas di lembaga pemasyarakatan anak pria Tangerang (Disertasi tidak dipublikasikan). Universitas Bina Nusantara, Indonesia.

Putallaz, M., \& Heflin, A. H. (1990). Parent-child interaction. In S. R. Asher \& J. D. Coie (Eds.), Peer rejection in childhood (hlm. 189-216). New York, NY: Cambridge University Press.

Riduwan. (2006). Metode dan Teknik Penyusunan Tesis. Bandung: Alfabeta.

Rozi, F., \& Muhyiddin, N. (2013). The influence of video game on aggression and anger. Proceedings of the 21-st International Conference on Computers in Education ICCE 2013, 645-647. 
Rudy, D., \& Grusec, J. E. (2006). Authoritarian parenting in individualist and collectivist groups: Associations with maternal emotion and cognition and children's self-esteem. Journal of Family Psychology, 20(1), 68-78.

Santrock, J. W. (1995). Life-span development: Perkembangan masa hidup, edisi 5, jilid II. Jakarta: Erlangga.

Santrock, J. W. (2002). Life span development, jilid 2. Jakarta: Erlangga.

Santrock, J. W. (2003). Perkembangan masa remaja. Jakarta: Erlangga.

Santrock, J. W. (2007). Remaja, jilid 1 (11th ed.). Jakarta: Erlangga.

Sarwono, S.W. (1999). Psikologi Sosial. Jakarta: Balai Pustaka.

Saxena. P. (2005). A comparative study of frustration among working and non- working women. International Research Journal, 2(5), 446-448.

Shahida, B. S. (2013). Lack of adequate parenting: A potential risk factor for aggression among adolescents. Pakistan Journal of Psychological Research, 28(2), 217-238.

Supraptik., \& Sumarmo. (2003). Pengantar Psikologi Klinis. Jakarta: UI Press.

Wade, C, \& Travis, C. (2007). Psikologi, jilid 2 (P. Mursalin \& Dinastuti, Penerj.). Jakarta: Erlangga.

Zhou, Q., Eisenberg, N., Wang, Y., \& Reiser, M. (2004). Chinese children's effortful control and dispositional anger/frustration: relations to parenting styles and children's social functioning. Developmental psychology, 40(3), 352-366. 